\title{
Pinheiro Chagas e os nefelibatas
}

\section{Alvaro Santos Simões Junior}

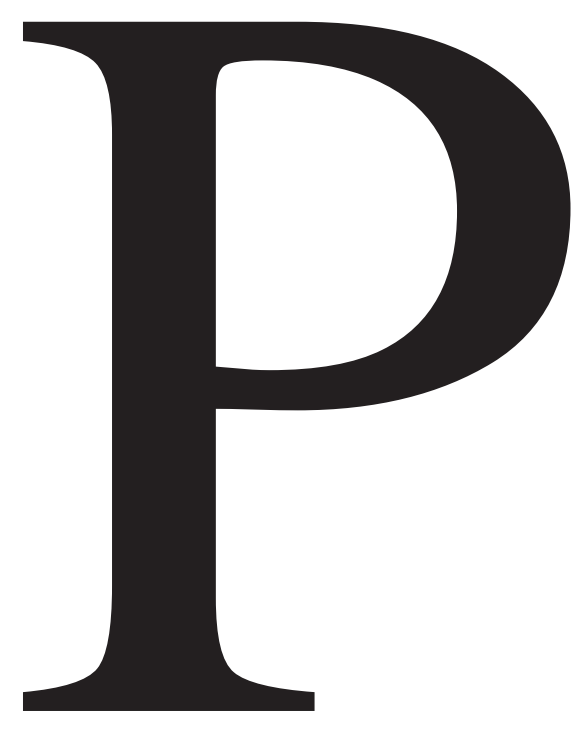

\section{PINHEIRO CHAGAS, CORRESPONDENTE}

\section{EUROPEU DO MATUTINO O PAÍS}

inheiro Chagas atuou como colaborador regular do diário carioca $O$ País de 1884 até sua morte, ocorrida em 1895. Do alto dessa tribuna, pôde acompanhar o surgimento e a afirmação em Portugal de uma nova geração de poetas que procurava introduzir em sua pátria as novidades decadentistas/simbolistas difundidas principalmente pela França. Com dois artigos, publicados em 9 de janeiro ("Os Nefelibatas") e 19 de julho de 1892 ("Só"), o dramaturgo, jornalista e poeta português avaliou as principais obras dos chamados novos de então, a saber: Oaristos (1890) e Horas (1891), de Eugénio de Castro, e Só (1892), de António Nobre. Quando esses artigos já suscitavam comentários em Lisboa, graças a alguns números do jornal carioca que passavam 
de mão em mão e a transcrições de fragmentos na imprensa, o Correio da Manhã, dirigido pelo próprio Pinheiro Chagas, publicou os artigos na íntegra em $1^{\circ}$ de fevereiro e 15 de agosto de 1892 , respectivamente. A respeito de Os Simples (1892), do veterano Guerra Junqueiro, o primeiro texto foi publicado em 3 de junho de 1892 no periódico lisboeta para somente depois ser transcrito na folha carioca. No entanto, o texto de O País, publicado em 16 de agosto de 1892, continha acréscimos que não constavam da primeira publicação e eram essencialmente favoráveis ao autor de A Velhice do Padre Eterno. Considera-se de algum interesse avaliar, além do conteúdo desses textos, as repercussões que provocaram em Portugal, onde desencadearam acirrada polêmica, e no Brasil, onde, graças a eles, os leitores não puderam ficar indiferentes ao acirrado debate estético então em curso na antiga metrópole. Esse talvez fosse um episódio importante do processo de difusão das ideias decadentistas/simbolistas no país de Cruz e Sousa.

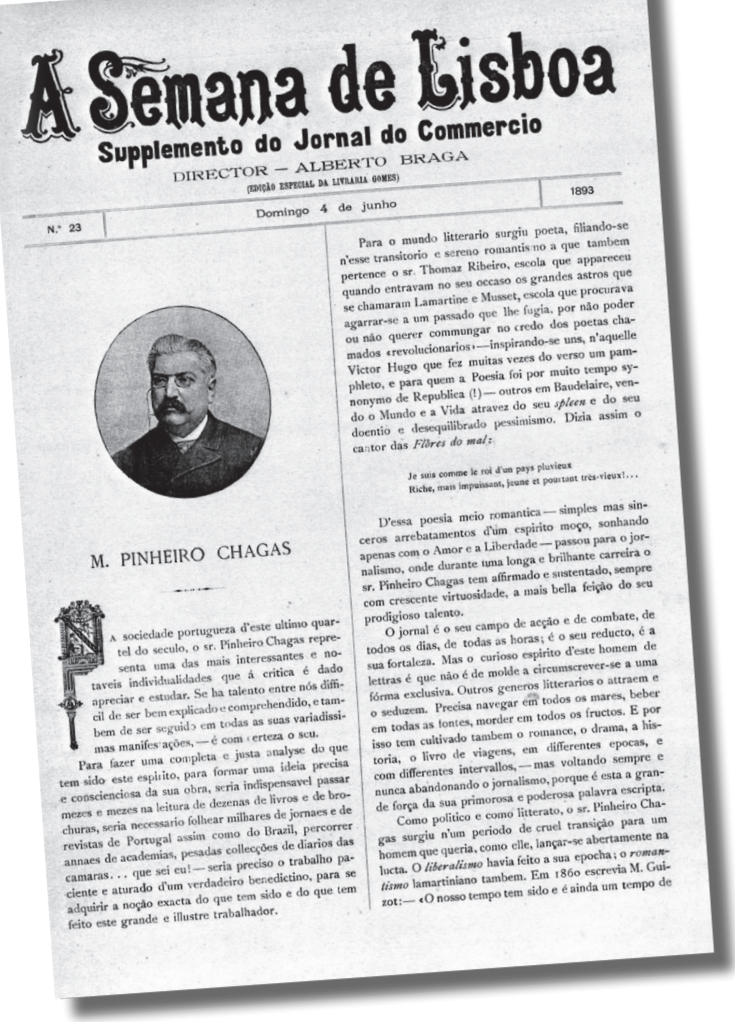

Primeira página do suplemento do Jornal do Comércio, de 4 de junho de 1893, com retrato de Pinheiros Chagas

\section{EUGÉNIO DE CASTRO, "CHEFE" DOS NEFELIBATAS}

Antecedente importante da intervenção de Pinheiro Chagas foi a intensa repercussão na imprensa dos livros de poesia publicados por Eugénio de Castro em 1890 e 1891, Oaristos e Horas, respectivamente. O poeta dotou ambas as obras de prefácios polêmicos. No primeiro, de Oaristos, dirigiu suas farpas contra a poesia portuguesa contemporânea, que dizia estar assentada "sobre algumas dezenas de coçados e esmaiados lugares-comuns" e empregar rimas e vocabulário "de pobreza franciscana". Seu Oaristos, ao contrário, seria o primeiro livro em Portugal a defender "a liberdade do Ritmo contra os dogmáticos e estultos decretos dos velhos prosodistas" e a adotar o "desconhecido processo da aliteração", além de ornar-se de "rimas raras, rutilantes" e vocabulário "escolhido e variado" (Castro, 1890, pp. v-viii). No segundo prefácio, das Horas, o poeta definiu sua nova obra como "silva esotérica para os Raros apenas", que teria sido concebida "longe dos bárbaros", cujos "inscientes apupos" não conseguiriam afastá-lo de "seu nobre e altivo desdém de nefelibata" (Castro, 1891, pp. v-vi).

Os bárbaros em questão seriam todos aqueles que, na imprensa, haviam criticado e parodiado sua primeira obra e que, a partir de então, iriam passar a empregar a designação de nefelibata para se referirem jocosamente aos jovens poetas, isto é, os raros que flertavam com a estética decadentista-simbolista.

A despeito das críticas e paródias, que também seriam endereçadas às Horas, a imprensa portuguesa atribuiu ao seu autor certo protagonismo ou liderança diante de sua geração. Em 6 de julho de 1891, por exemplo, $O$ Globo iria referir-se a Eugénio de Castro como "o príncipe dos nefelibatas portugueses" (Prosas e Versos, 1891, p. 3), mas a verdadeira consagração ocorreria no mês seguinte, quando Xavier de Carvalho publicasse resenha de Enquête sur l'Évolution Littéraire, obra em que Jules Huret reuniu entrevistas com vários dos principais escritores franceses. Carvalho destacou da entrevista de René Ghil as palavras com que o poeta francês referiu-se ao "príncipe": 


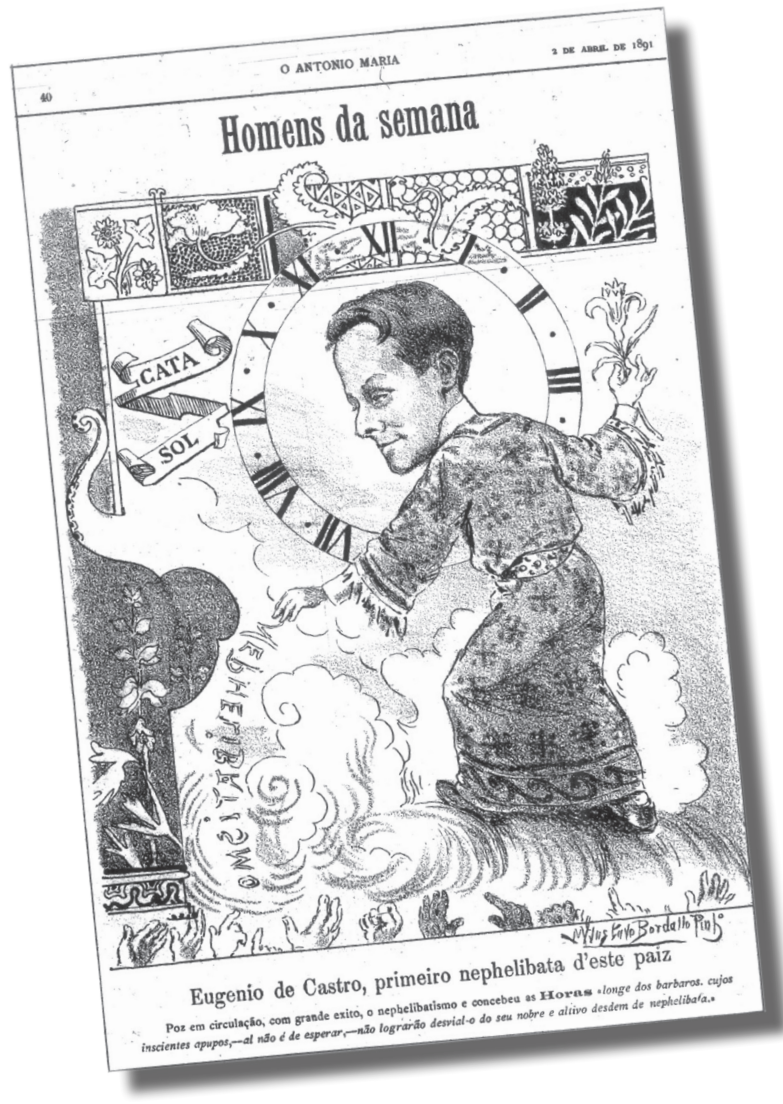

Portrait-charge de Eugénio de Castro por Manuel Gustavo Bordalo Pinheiro a propósito da publicação das Horas (O António Maria, Lisboa, v. 7, n. 298, p. 40, 2 de abril de 1891)

"M. Eugénio de Castro, poete portugais qui par cinq ou six livres (dont les deux derniers très remarquables Oaristos et Horas) est en sa patrie le chefe [sic] d'un mouvement de rénovation. Écrivant parfaitement notre langue, il s'est rallié à la méthode évolutive pour laquelle il luttera au Portugal" (apud Carvalho, 1891, p. 1)1.

Xavier de Carvalho (1891, p. 3) concluiu que a declaração de Ghil deveria "encher d'orgulho o novel poeta português".

No dia seguinte, já se ouvia o primeiro eco da resenha n'O Diário Popular, onde se publicara uma nota maliciosa: "Está nomeado, pois, oficialmente, Eugénio de Castro chefe dos nefelibatas em Portugal, pese o que pesar ao insurgido D. João

1 No livro, não há a abreviação de Messier e, após luttera, lê-se également (Huret, 1891, p. 115). de Castro que já declarou não lhe reconhecer a chefatura" (O Chefe, 1891, p. 2).

\section{O ESCÁRNIO DO CONSELHEIRO CHAGAS}

No entanto, a principal reação à investidura seria conhecida somente no início de 1892 , quando repercutia em Portugal artigo publicado por Pinheiro Chagas no jornal carioca $O$ País, em 9 de janeiro. As Novidades foram o primeiro jornal português a dar notícia do texto no dia 25 do mesmo mês, transcrevendo os dois primeiros parágrafos (Os Nefelibatas, 1892a); dois dias depois, foi a vez d'O Diário Popular, que deu muito mais importância ao artigo, transcrito quase integralmente, e garantiu que nele os nefelibatas haviam sido "cruelmente maltratados" (Os Nefelibatas, 1892b). A publicação integral ocorreria em $1^{\circ}$ de fevereiro de 1892, no Correio da Manhã, que era dirigido pelo próprio Pinheiro Chagas. Segundo Seabra Pereira, esse texto representava uma consagração à rebours, pois o famoso escritor havia produzido textos críticos ou satíricos sobre "todas as escolas e agrupamentos da segunda metade do século XIX” (Pereira, 1975, p. 185).

Os parágrafos transcritos pelas Novidades continham uma zombaria a propósito da menção a Eugénio de Castro na entrevista concedida por René Ghil a Jules Huret. Chagas procurou diminuir a importância que se atribuiu em Portugal ao autor dos Oaristos informando que ele era apenas um dos muitos seguidores do poeta francês:

“[...] devemos dizer, para glória do nosso patrício, que René Ghill [sic] declarou que a escola evolutivo-instrumentista tinha por esse mundo todo vinte e seis adeptos. Vinte e seis instrumentistas! Não é uma escola, é uma filarmônica.

Ora, entre esses vinte e seis instrumentistas evolutivos, cujos nomes o Sr. René Ghill [sic] confiou ao Sr. João Huret, figura - ó glória nacional! - o Sr. Eugénio de Castro. É sempre agradável ver que a nossa pátria figura n'esses grandes acontecimentos do espírito humano. Quando Santo Inácio de Loiola ${ }^{2}$ reuniu na coli-

2 Fundador da Companhia de Jesus, a famosa ordem dos jesuítas. 
na de Montmartre os seus primeiros aderentes, lá estava um português - Simão Rodrigues de Azevedo. Quando o Sr. René Ghill [sic] faz em Paris a enumeração dos seus vinte e seis irmãos de armas - lá está um português - o Sr. Eugénio de Castro. Ainda bem que temos um instrumentista n'aquela banda. O Brasil não se lambeu com ele! Surriada!" (Chagas, 1892a, p. 2).

Depois da chacota, que colocava em dúvida a honra de figurar em uma longa enumeração com a qual Ghil pretendia claramente apenas evidenciar o acolhimento geral de suas ideias, disse Chagas não ser sua intenção "motejar" dos inovadores, porque estes disso "tirariam glória dizendo que foi sempre o motejo dos rotineiros que acolheu os fundadores das novas escolas". Para o jornalista, o que principalmente depunha contra as "novas escolas de poesia" era a "indiferença pública", pois, se a crítica era "renitente às inovações e hostil aos inovadores", o público mostrava-se "sempre do partido d'eles" (Chagas, 1892a).

Chagas também se insurgiu contra a veleidade de criarem-se escolas poéticas, pois, segundo ele, as mudanças literárias resultariam "da evolução natural do espírito humano". Para comprovar essa afirmação, esboçou em linhas gerais a história da literatura universal do renascimento ao romantismo. Segundo seu relato, as mudanças ter-se-iam feito necessárias porque "uma literatura precisa de corresponder ao estado de espírito de seu século"; mas para que um artista pudesse corresponder à necessidade de mudança devia ser essencialmente sincero, pois a sinceridade seria "qualidade indispensável dos poetas" (Chagas, 1892a).

O crítico concluiu o seu artigo oferecendo paternalmente conselhos aos novos poetas:

"Portanto caros evolucionistas instrumentistas, convencei-vos de que nada conseguis com as vossas caixinhas de papelão, com os vossos artifícios por mais sábios que sejam. Se trazeis uma ideia nova, apresentai-a sem hesitação, porque será acolhida com entusiasmo, por mais extravagante que seja. Se trazeis apenas uma moda nova, podeis incitar alguns excêntricos a segui-la, mas passa depressa, muito mais depressa do que passou a das 'preciosas ridículas'..." (Chagas, 1892a).

\section{UMA CONTUNDENTE CARTA ABERTA}

A resposta de Eugénio de Castro a Pinheiro Chagas demorou alguns dias, mas veio firme e forte. O jovem poeta, que por quase dois anos havia suportado com impassibilidade nefelibata as críticas e zombarias de boa parte da imprensa, decidiu reagir quando críticas irônicas partiram de um medalhão consagrado, que era deputado, professor do Curso Superior de Letras, oficial do Exército, diretor de um jornal importante, o Correio da Manhã, e ex-ministro da Marinha (1883-1886). Chagas destacava-se na literatura portuguesa como polígrafo e autor de obras populares como, por exemplo, os romances históricos Tristezas à Beira-mar (1866) e A Mantilha de Beatriz (1878) e o drama em cinco atos A Morgadinha de Valflor (1869). Contando na ocasião 50 anos, já havia inscrito o seu nome na história da literatura portuguesa, pois a carta-posfácio de uma obra sua, $O$ Poema da Mocidade (1865), desencadeara a Questão Coimbrã. Nesse texto António Feliciano de Castilho recomendava Chagas para o cargo de professor de Literaturas Modernas no Curso Superior de Letras de Lisboa e criticava a nova geração de intelectuais conimbricenses que então surgia, dela citando nominalmente Teófilo Braga, Antero de Quental e Vieira de Castro. O primeiro jovem escritor a replicar a Castilho foi Antero de Quental, com o opúsculo "Bom Senso e Bom Gosto", que tinha a forma de "carta ao Excelentíssimo Senhor António Feliciano de Castilho". Como deputado em primeiro mandato, Pinheiro Chagas apoiou e defendeu no Parlamento em 1871 a decisão do governo português de proibir as Conferências Democráticas do Cassino Lisbonense, colocando-se novamente em rota de colisão com os intelectuais mais dinâmicos e brilhantes de sua geração, que lutavam contra o atraso político, científico e cultural de seu país. Em 1887, como relator do júri constituído para o Prêmio D. Luís I, preteriu A Relíquia, de Eça de Queirós, em favor de Os Amores de Júlia, romance histórico de José 
Maria de Sousa Monteiro (Buesco, 2005, pp. 1.113-4; Iannone, 1973, pp. 9-13) ${ }^{3}$, hoje caído no esquecimento.

A "Carta ao Sr. Conselheiro Chagas" contém em seu início uma explicação para o silêncio com que até então Eugénio de Castro havia recebido as críticas da imprensa:

“[...] nunca respondi às prosas mais ou menos agressivas que me foram consagradas nos jornais, em primeiro lugar: porque na minha qualidade de Artista sinto que não devo vir esgrimir em público com criaturas que não conheço, e porque, sendo a Crítica uma função subalterna da Arte, não posso sofrer que um diretor geral vá fazer o serviço d'um amanuense; em segundo lugar: porque, não lendo jornais (como V. Exa. vê, sou como o Fontes ${ }^{4}$ ), d'essas prosas tive apenas um conhecimento muito vago, por ouvir dizer; finalmente: porque, contentando-me com a consideração dos que a merecem, me conservo absolutamente indiferente perante as opiniões dos que as não têm" (Castro, 1892, p. 1).

Em seguida, declarou Castro haver recebido a edição d'O País, do Rio de Janeiro, das mãos de um amigo e ter lido o artigo do amanuense Chagas "com a mais viva gula, com o mais intenso pra-

3 Em termos laudatórios, cronista contemporâneo narrou à sua maneira os conflitos entre Chagas e a geração de 70: "O Sr. Pinheiro Chagas aparecendo para as letras e para a política nas alturas de 1860 , e deixando-se seduzir pelas últimas manifestações d'uma geração político-literária que se achava no seu ocaso, tinha de ficar quase isolado no meio das novas gerações, como sendo o representante d'um mundo que pouco a pouco amortecia - um dos últimos abencerragens do liberalismo e do romantismo agonizantes. Ter-lhe-ia sido fácil passar para as novas seitas e novas escolas. O seu talento desabrochava então. Não o fez porém; e isto é um valioso testemunho de que o seu caráter também iguala o seu talento. Quis sustentar hasteada a bandeira furada pelas balas inimigas, mas que era imagem de passadas e gloriosas vitórias... E conservou-a erguida com uma coragem e um vigor excepcionais, lutando peito a peito, ele só, sempre na brecha, contra os troços da gente nova que chegava, disputando ferozmente o terreno. As suas campanhas literárias lembram, pela firmeza, pela coragem, pela audácia no ataque, as lutas sustentadas na Revue des Deux Mondes pelo eminente crítico Sr. Ferdinand Brunetière, contra a onda dos sectários de Flaubert, de Zola e dos irmãos de Goncourt" (Pina, 1893, pp. 177-9).

4 Menção provável a António Maria de Fontes Pereira de Melo, então já falecido, que fora presidente do Conselho de Ministros. zer", o que o levou a abandonar seus "propósitos de silêncio" em função do "fundo agradecimento" pelas "boas intenções" do Conselheiro, apesar de "algumas frases amargas". Esclareceu o poeta dos Oaristos que a exceção não significava menor apreço aos "outros inimigos", mas resultava de seu respeito pelas "cãs", mesmo quando estas alvejassem em "espíritos decrépitos". Para deixar claro que a decrepitude em questão era exclusivamente intelectual e que se opunha às ideias esposadas pelo adversário, Castro acrescentou: "V. Exa., que fisicamente é quase um moço ainda, literariamente é velhíssimo. Já fez o que tinha a fazer, ou antes o que nunca devia ter feito" (Castro, 1892a). Ao referir-se à farta cabeleira grisalha do Conselheiro, Castro reproduzia a atitude irreverente adotada 16 anos antes por Antero de Quental em seu confronto com Castilho. No seu panfleto "Bom Senso e Bom Gosto", o poeta das Odes Modernas aludiu por duas vezes, sarcasticamente, à cegueira de seu antagonista e, ao final, declarou seu temor de ter faltado ao respeito devido aos cabelos brancos de Castilho, mas apresentou uma justificativa para a irreverência:

"Levanto-me quando os cabelos brancos de V. Exa. passam diante de mim. Mas o travesso cérebro que está debaixo e as garridas e pequeninas coisas, que saem dele, confesso não me merecem nem admiração nem respeito, nem ainda estima. A futilidade num velho desgosta-me tanto como a gravidade numa criança" (Quental, 1999, pp. 146-57).

Depois do início irônico, entrando a analisar o conteúdo do artigo de Chagas, Eugénio de Castro repudiou a designação de "nefelibata" que o diretor do Correio da Manhã lhe aplicara, pois a considerou deselegante pela maneira como circulava nos diários, nos quais era empregada como sinônimo de "fariseu", "amalucado", "charlatão", etc. Além de conceder-se o refinado prazer de corrigir os erros do Conselheiro, que no seu artigo trocara Jules Huret por João Huret e René Ghil por René Ghill (com dois $l l$ ), o autor das Horas assim respondeu à boutade da "filarmônica" dos instrumentistas: "Fora eu vingativo, e chamaria V. Exa. o "homem dos sete instrumentos"'. Como se nota facilmente, Castro assim aludia às múltiplas atribuições e responsabilidades de seu antagonista, sempre hábil 
em adaptar-se convenientemente a situações novas e obter vantagens pessoais.

O jovem poeta ainda se empenhou em evidenciar engano de Chagas, que o filiara à escola evolutivo-instrumentista de Ghil, alegando não estar preso a nenhuma "seita" e divergir do doutrinador francês, apesar de manter com ele boas relações de amizade e colaborar nos seus jornais. Quanto à frieza do público diante dos seus livros, a qual seria, segundo Chagas, prova da mediocridade deles, assim se pronunciou:

"Permita-me V. Exa. que lhe observe que o público que riu dos meus poemas foi o mesmo que aplaudiu a Morgadinha de Val Flor [sic], e que se riu dos versos de oiro de Cesário Verde, o mesmo que aplaude a pintura industrial de Malhoa e que se ria alvarmente da obra, cheia de gênio, de Columbano".

Deve-se notar que, implicitamente, o jovem poeta alinhava-se com um poeta de valor reconhecido e, ao mesmo tempo, colocava-se como antípoda de quem recebera a consagração popular, considerada por ele comprovação de obra medíocre. No caso da pintura, caracterizou negativamente como "industrial" a obra do naturalista José Vital Branco Malhoa, que, bem recebido pela burguesia, representava em suas telas "o real vivido dum bom povo debaixo do bom sol rural, em suas festas e dramas, seus prazeres e sua paciência ancestral"; em pleno período de crise pós-Ultimatum, expunha telas amenas com paisagens rurais e costumes populares (França, 1987, pp. 22-3). Já a obra de Columbano Bordalo Pinheiro, que Eugénio de Castro considerava "cheia de gênio", era constituída de retratos velados e espectrais de personalidades-chave do Portugal de fim de século, como Eça de Queirós, Oliveira Martins e Antero de Quental. Rejeitando o convencionalismo acadêmico, respeitado por Malhoa, Bordalo Pinheiro incorporava à sua arte elementos impressionistas e já expressionistas. Assim, representava um "Portugal doloroso, preso na urbe jamais figurada mas adivinhada no impossível lado de fora dos retratos pintados" (França, 1987, p. 48), em lugar do Portugal solar de Malhoa. Nessa comparação entre os dois artistas, já se esboçava a distinção que seria por ele proposta em 1893 entre cosmopolitas, com os quais se identificava, e nacionalistas, os quais seguiam o programa neogarrettiano traçado por Alberto de Oliveira (Castro, 1893, p. 1).

Nesse ponto, Castro suspendeu bruscamente a apreciação do artigo de Chagas alegando ter-se dado conta de que não lograria fazer-se compreendido, graças às profundas e irredutíveis diferenças com o seu antagonista: "V. Exa. vê amarelo o que eu vejo encarnado, verde o que eu vejo azul"; "V. Exa. quer a arte para toda a gente, eu quero a arte para meia dúzia”. Da consciência dessas incompatibilidades, decorreu a decisão de retomar o seu orgulhoso silêncio:

"V. Exa. perdeu o seu tempo lendo-me, eu perdi o meu tempo escrevendo-lhe.

Termino, pois, e volto ao meu silêncio, onde, para regalo do meu orgulho, me bastam as quentes saudações que a imprensa estrangeira imparcial, inteligente e honrada, me tem dirigido e as altas palavras que particularmente me têm enviado todos os que no estrangeiro têm um Nome (com N grande): Edmond de Goncourt, J. K. Huysmans, Iwan Gilkin, Maurice Maeterlinck, Jean Moréas, Paul Adam, Rollinat, S. Mallarmé, Curros y Enriquez, Barrès, Ghil, Príncipe de Deslandes, Brinn'Gaubast, etc., etc." (Castro, 1892, p. 1).

Iniciada a polêmica com a notícia do reconhecimento internacional de Eugénio de Castro, o poeta das Horas procurou encerrá-la definitivamente oferendo provas abundantes do prestígio que acumulara fora de Portugal, onde ainda havia, segundo ele, imprensa "imparcial, inteligente e honrada". Insinuava, assim, que sua terra não estava tão bem servida... Dava também a entender que no exterior espíritos elevados sabiam reconhecer espontaneamente o seu valor. Em "Bom Senso e Bom Gosto", Antero de Quental não mencionou relações internacionais tão próximas, mas procurou mostrar-se alinhado com contemporâneos como Stuart Mill, Jules Michelet e Hippolyte Taine, entre outros grandes pensadores.

No fecho de sua carta, Castro disse a Chagas que este não deveria espantar-se com o fato de que não iria declarar-se, como impunham as regras de cortesia, "seu admirador", uma vez que admirava "pouquíssimas pessoas" na literatura portuguesa. Encerrando o seu panfleto, Antero de Quental fize- 
ra preceder o seu nome da inusitada fórmula "nem admirador nem respeitador".

A polêmica da "chefatura" terminou, na imprensa, com essa intervenção de Eugénio de Castro, mas meses depois Jaime Vítor, que era o braço direito de Pinheiro Chagas no Correio da Manhã, iniciou nesse mesmo diário uma série de textos críticos ou satíricos contra o suposto líder nefelibata.

\section{ANTÓNIO NOBRE SEGUNDO CHAGAS: UM POETA DE TALENTO, APESAR DO SEU NEFELIBATISMO}

Último a pronunciar-se sobre o Só, de António Nobre, Pinheiro Chagas o fez de um modo tortuoso. Primeiramente publicou seu artigo em 19 de julho de 1892 em $O$ País, do Rio de Janeiro; depois, fragmentos foram transcritos na edição de 8 de agosto d'O Diário Popular; por fim, a publicação integral ocorreu cinco dias depois, no Correio da Manhã, cujo diretor era o próprio Chagas, que destacou, logo no início de seu texto, o tom "desalentador, desesperador, soturno, lúgubre" do livro, cuja única nota seria "a do desgosto da vida, a do entusiasmo pela morte, pelo caixão, pelos espectros, pelos ciprestes". Chagas expressou seu temor de que Nobre houvesse conseguido traduzir em seu livro os sentimentos da juventude portuguesa:

"Se a geração a que pertence o Sr. António Nobre está efetivamente n'aquela afinação, ou antes n'aquela desafinação suprema! Se está d'esta forma desossada com os versos desarticulados dos poetas das escolas novas, decadente, deliquescente, fatigada sem ter trabalhado, enervada sem ter lutado, que pífia geração, que geração sifilizada e dessorada, sem músculos e sem sangue que tem de carregar com o peso das grandes tradições do passado, e dos graves problemas do futuro!" (Chagas, 1892b, p. 1).

A conclusão a que chegou sobre os jovens poetas foi totalmente sarcástica:

"Nasceram velhos, a sua primeira infância é a segunda! Na idade em que os Romanos toma-

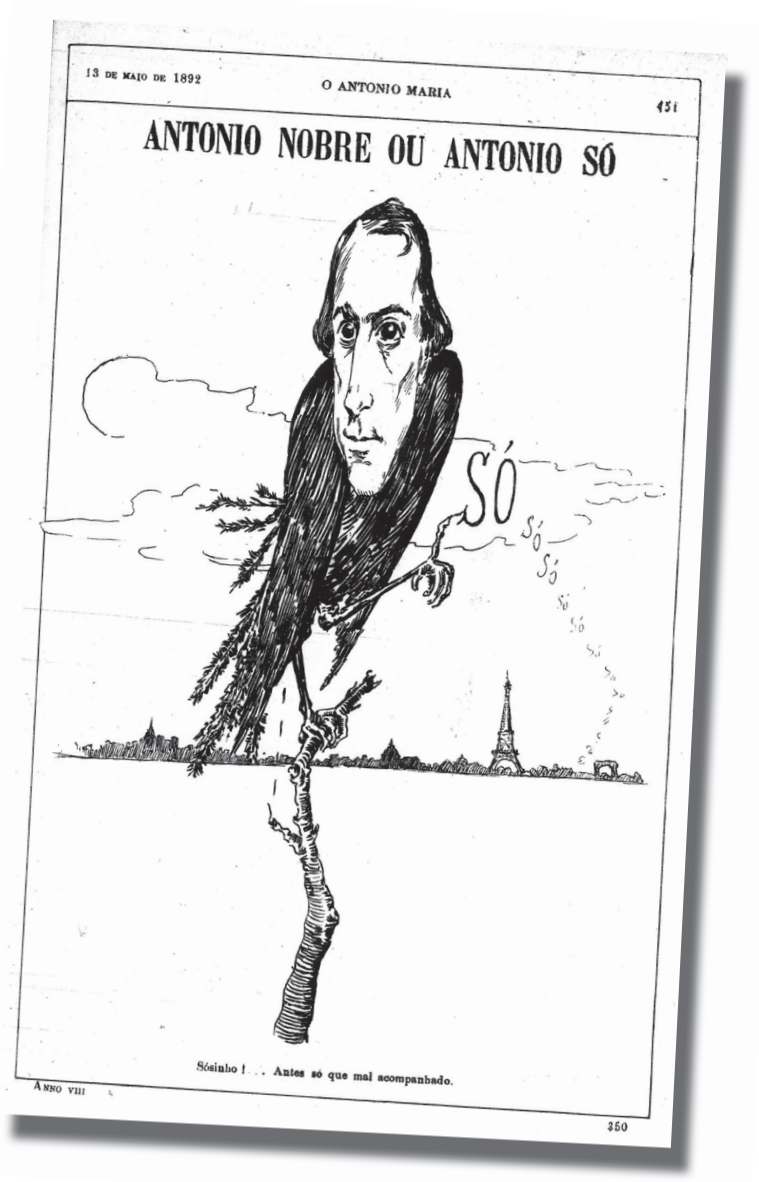

Charge de António Nobre por Rafael Bordalo Pinheiro alusiva à publicação do Só por Léon Vanier (O António Maria, Lisboa, v. 8, n. 350, p. 451, 13 de maio de 1892).

vam a toga viril, põem eles bibes! Tem a gente vontade de lhes dizer: 'Os meninos querem fazer ó... ó'. O Sr. António Nobre, quando fala de si, diz sempre 'O António!' Coitadinho do bébé" (Chagas, 1892b, p. 1).

Chagas comparou o "desespero soberbo" de Alfred de Musset e o "riso satânico" de Baudelaire com a postura da nova geração portuguesa para dizer:

"Estes agora fazem uma lamúria babosa, têm sempre na boca Nossa Senhora, rezam pelas suas contas, não usam senão diminutivos - a sombrinha da árvore, e o António sãozinho, e a menina purinha, e a flor branquinha. Fazem uma literatura gaga os demônios dos rapazes. Se são 
eles efetivamente os que exprimem o estado de alma de uma geração inteira, olhem que bonita geração!" (Chagas, 1892b, p. 1).

$\mathrm{O}$ articulista condenou a artificialidade e o convencionalismo da restauração dos "mistérios medievais e as chácaras ingênuas do tempo das cruzadas" e viu até mesmo "profanação" em submeter "imagens lúgubres" e "sentimentos angustiosos" a "puerilidades" formais como os tipos de diverso tamanho, adotados no Só.

Apesar de tantas restrições, Chagas reconheceu em António Nobre "extraordinário talento", capaz de expressar "uma angústia verdadeira, uma dor lancinante, uma saudade sincera" e, como demonstração do que dissera, transcreveu do Só o poema "Pobre Tísica!", considerado por ele "verdadeira obra-prima".

O texto não se encerraria sem que o crítico tratasse jocosamente de uma das supostas extravagâncias do poeta, que, no poema " $\mathrm{Ca}$ (ro) $\mathrm{Da}$ (ta) Ver(mibus)", chamou a lua de "leiterinha/ Que vai dar leite às casas do infinito":

"O Sr. António Nobre encontrava-se em presença do Sr. Eugénio de Castro, que tinha feito a lua padeira com a farinha do luar. Tratava-se de encontrar outra ocupação em que houvesse coisas brancas, e foi por isso que a fez leiteira. O que fica para os outros?" (Chagas, 1892b, p. 1).

Apesar de tudo, Chagas expressou ao final sua confiança em que o jovem poeta, por virtude do seu talento, acabaria por libertar-se dos artificialismos da nova poética. Se se pode conceber uma oposição irredutível entre os principais poetas da geração nefelibata, é possível afirmar que Pinheiro Chagas resolvera colocar-se, à sua maneira, ao lado de António Nobre, combatendo assim o protagonismo que então se atribuía a Eugénio de Castro.

\section{PINHEIRO CHAGAS E}

\section{GUERRA JUNQUEIRO}

Sobre Os Simples, de Guerra Junqueiro, Chagas publicou em 3 de junho de 1892 breve apreciação no Correio da Manhã , sob anonimato. No diário carioca $O$ País, edição de 16 de agosto de
1892, Pinheiro Chagas complementou o primeiro texto com novas considerações sobre o livro. $\mathrm{Na}$ resenha anônima publicada no jornal português, há breves considerações sobre vários poemas do livro, mesclando-se elogios e reparos críticos. Embora reconhecesse que Os Simples possuíam "páginas verdadeiramente admiráveis", começou por observar que "fatiga[va] às vezes um pouco" a "repetição quase incessante do mesmo ritmo" (Chagas, 1892c, p. 1), problema que já fora apontado por Armando Navarro (1892, p. 3). Depois de dizer que se entusiasmara com o "Prelúdio", afirmou que Junqueiro quis, com a "A Moleirinha", provar que, ao "fazer nefelibatismo", o fazia "melhor que todos os outros juntos". Desse poema, citou versos em que se atribuem pensamentos a um burrico, para quem as estrelas eram "milho loiro" e a lua, "mó de jaspe". O trecho suscita comentário sarcástico de Chagas:

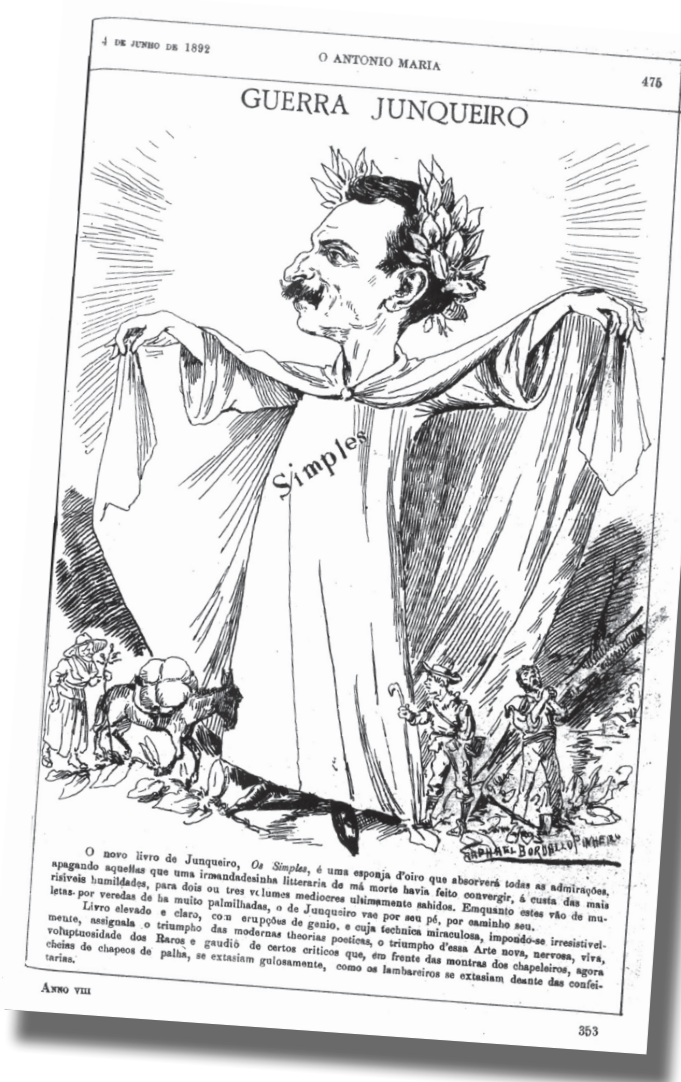

Portrait-charge de Guerra Junqueiro por Manuel Gustavo Bordalo Pinheiro a propósito da publicação do livro Os Simples (O António Maria, Lisboa, v. 8, n. 353, p. 475, 4/jun./1892) 
"O Sr. Eugénio de Castro fez da lua peneira, o Sr. António Nobre leiteira ${ }^{5}$ o Sr. Guerra Junqueiro mó de moinho. A noite para o Sr. Eugénio de Castro é padeira, para o Sr. António Nobre, dona de uma vacaria, para o Sr. Guerra Junqueiro, moleira. Pobre noite! E pobre lua! Caíram em boas mãos!".

Se para Chagas o poema "O Cadáver" era "admirável", "ermidas", "encantador", e "O Pastor", uma "obra-prima", o "Campo Santo" não passava de uma "estopada". Já "O Cavador", que considerou uma "poesia dilacerante de tom", ficaria, em sua opinião, prejudicado pelo cansaço proporcionado pelo "dobre de sinos constante" do restante do livro. Para Chagas, o poema publicado no "Epílogo" seria "soberbíssimo"; dele transcreveu uma estrofe que teria feito "correr as lágrimas de um modo irresistível" (Chagas, 1892c, p. 1).

Na continuação escrita apenas para os leitores brasileiros, o cronista desenvolveu um pouco mais a comparação entre o "Prelúdio", parte inicial, e o "Epílogo", que contém o último poema do livro, intitulado "Regresso ao Lar". Chagas condenou a solução alegórica adotada para o primeiro, porque, em sua opinião,

"[...] quando um poeta de gabinete, um épico erudito, ainda que se chame Virgílio, começa a fazer esforços para criar alegorias, para transformar em entes que a sua fantasia laboriosamente fabrica os seres da vida real, os sentimentos da sua alma, nada há mais fatigador e mais fastidioso".

Após prever que Junqueiro ainda seria reconhecido como "um dos grandes poetas portugueses" do século XIX, que de A Morte de D. João e A Velhice do Padre Eterno sobreviveriam "largos trechos" do "naufrágio" do conjunto, e que de $A$ Musa em Férias e Os Simples seria extraída uma "seleta" destinada a "encantar" os pósteros, Chagas acusou o poeta de escrever "A Moleirinha",

5 Pinheiro Chagas alude às Horas, de Eugénio de Castro, onde se lê: "E a Padeira-Noite põe-se a peneirar/ $\mathrm{Na}$ peneira-Lua a farinha-Luar" (Castro, 1891, p. 21). No caso de António Nobre, refere-se ao primeiro terceto do poema " $\mathrm{Ca}$ (ro) $\mathrm{Da}$ (ta) Ver(mibus)", que consta da primeira edição do Só (1892, p. 126-31). Os versos de Nobre são os seguintes: "Às horas do crepúsculo, ao Bendito,/ Quando a formosa Lua, a leiterinha,/ Vai dar o leite às casas do Infinito...". com suas onomatopeias, por não gostar de ser precedido por "inovadores de qualquer espécie", por receio de ser considerado "fora de moda", por temer que o público abandonasse Os Simples para "se extasiar com as audácias do Só, de António Nobre", e por não se conformar com "um passageiro eclipse da popularidade que o inebria[va]". No fragmento final, o cronista toma o poema "Cadáver" como indício de inflexão no espírito do poeta, que, invadido por um "sopro panteístico", já não seria capaz de escrever o prometido livro A Morte de Jeová. Não era, assegurava, a conversão completa do poeta ao catolicismo, mas indicação de que sua alma voltava-se, "compungida e anelante, para os ideais da crença, ainda vaga e indefinida" (Chagas, 1892c, p. 1).

\section{UMA CONSAGRAÇÃO ÀS AVESSAS}

Pode-se concluir que Pinheiro Chagas retardou, talvez de caso pensado, todas as três intervenções aqui citadas, pois quando publicou seus textos todos os livros analisados, isto é, Oaristos, Horas, Só e Os Simples, já haviam recebido a atenção da imprensa periódica, sofrendo críticas semelhantes às que ele formulara. No caso das obras de Eugénio de Castro e António Nobre, sua estratégia de publicar primeiramente no diário carioca $O$ País criou em Portugal a expectativa de conhecer os textos em sua íntegra. Repassados de ironia, seus três textos críticos têm claramente o objetivo de condenar as extravagâncias ou ousadias decadentistas/simbolistas, apenas reconhecendo convencionalmente o talento de António Nobre e Guerra Junqueiro. Considerando romanticamente que era dever do poeta ser sincero, refutava por artificiosa a poesia nefelibata produzida, a seu ver, por imitação servil dos mestres franceses.

Como assinalou Seabra Pereira, ter sido dura e diretamente criticado por Pinheiro Chagas representou para Eugénio de Castro uma consagração às avessas, pois o diretor do Correio da Manhã era uma espécie de literato oficial e defendia ideias mais ou menos consensuais e convencionais no campo da literatura e das artes. Apontado por Chagas como uma ameaça ao statu quo literário, Eugénio de Castro adquiriu paradoxalmente liderança e autoridade moral 
junto aos seus companheiros de geração, interessados na renovação da literatura portuguesa, pela maneira desassombrada e irreverente como confrontou o medalhão consagrado, inserindo-se simbolicamente no grupo dos modernos intelectuais portugueses ao imitar a forma epistolar e o estilo contundente com que Antero de Quental se insurgira em 1865 contra António
Feliciano de Castilho, padrinho literário de Pinheiro Chagas.

Com sua tribuna privilegiada em $O$ País, o correspondente português talvez tenha estimulado no Brasil uma certa animosidade contra os que chamou de nefelibatas. Diga-se, a propósito, que esse termo teve deste outro lado do Atlântico larga circulação em sua acepção pejorativa.

\section{BIBLIOGRAFIA}

BUESCU, Helena Carvalhão. "Manuel Joaquim Pinheiro Chagas", in Biblos, Enciclopédia Verso das Literaturas de Língua Portuguesa. Lisboa, Verbo, 2005, v. 1, pp. 1.113-4. CARVALHO, Xavier de. "De Paris", in O Português. Lisboa, 23/ag./1891, pp. 1, 1-3 col. CASTRO, Eugénio de. Oaristos. Coimbra. Manuel de Almeida Cabral, 1890. Horas. Coimbra, Manuel de Almeida Cabral, 1891. "Carta ao Sr. Conselheiro Chagas", in Jornal do Comércio, Lisboa, 7/fev./1892, pp.

1,5-7 col. . “Cosmopolitas e Nacionalistas", in O Diário Popular. Lisboa, 27/jul./1893, pp. 1, 4 col.

CHAGAS, Pinheiro. "Os Nefelibatas", in Correio da Manhã. Lisboa, 1/fev./1892a, p. 1, 1-5 col. "Só", in Correio da Manhã. Lisboa, 13/ag./1892b, p. 1. . "Simples", in O País. Rio de Janeiro, 16/ag./1892c, pp. 1, 1-2. col.

FRANÇA, José-Augusto. Malhoa, o Português dos Portugueses, \& Columbano, o Português sem Portugueses. Lisboa, Bertrand, 1987.

HURET, Jules. Enquête sur l'Evolution Littéraire. Paris, Charpentier, 1891.

IANNONE, Carlos Alberto. "A Vida de Pinheiro Chagas", in Pinheiro Chagas. Tristezas à Beiramar. São Paulo, Três, 1973, pp. 9-13.

NAVARRO, Armando. "Os Simples por Guerra Junqueiro", in Novidades. Lisboa, 2/jun./1892, p. 3, 1-2 col.

NOBRE, António. Só. Paris, Léon Vanier, 1892.

O CHEFE dos Nefelibatas. O Diário Popular. Lisboa, 24/ago./1891, p. 2, 5 col.

OS NEFELIBATAS. Novidades. Lisboa, 25/jan./1892a, p. 2, 2 col. "Crítica Amarga", in O Diário Popular. Lisboa, 27/jan./1892b, p. 1, 6 col., p. 2, 1-3 col.

PEREIRA, José Carlos Seabra. Decadentismo e Simbolismo na Poesia Portuguesa. Coimbra, Centro de Estudos Românicos, 1975.

PINA, Mariano. M. "Pinheiro Chagas", in A Semana de Lisboa: Suplemento do Jornal do Comércio, v. 1, n. 23, 4/jun./1893, pp. 177-9.

PROSAS e Versos. O Globo. Lisboa, 6/jul./1891, p. 3, 1 col.

QUENTAL, Antero de. "Bom Senso e Bom Gosto", in Alberto Ferreira, Antologia de Textos da Questão Coimbrã. 2. ed. Lisboa, Litexa, 1999, pp. 146-57. 